\title{
14
}

\section{Negotiating the Melanesia Free Trade Area}

\section{Sovaia Marawa'}

Melanesia is gaining prominence as a powerful political and economic sub-region in the Pacific. The initial members of the Melanesian Spearhead Group (MSG) first signed the MSG Trade Agreement (MSGTA) in 1993 as the instrument to promote trade and regional integration in Melanesia. The MSGTA has been reviewed twice by its members to strengthen and improve its implementation, and in January 2013 a significant milestone was reached with the opening up of the largest regional market in the Pacific.

This chapter explores the significance of the MSG Free Trade Area (MSG-FTA) and how it has reached new heights, despite the experiences of trade wars on biscuits, kava, and beef. It also explains how it departs from the initial MSGTA and the reasons why it has been more successful than similar regional integration initiatives, such as the Pacific Island Countries Trade Agreement (PICTA). It then examines the three key factors contributing to the success of the MSG-FTA: the political will and leadership of MSG leaders to set a bold vision for closer economic integration, measures taken by members to make the

\footnotetext{
1 I would like to acknowledge Mrs Mere Falemaka, Pacific Islands Forum Ambassador to Geneva, for her editorial advice on this chapter. This is based on my research as a postgraduate student in the diplomacy program at the University of the South Pacific and should not be taken as the representing the official view of the Ministry of Foreign Affairs.
} 
MSG more relevant and improve the implementation of the MSGTA, and the prominent role played by Fiji and Papua New Guinea (PNG) in increasing trade and investment relations within Melanesia.

\section{Significance of the MSG-FTA}

In 2013, the MSG-FTA became operational, with its members now according reciprocal tariff treatment for originating or value-added products traded within the sub-region. ${ }^{2}$ Under the free trade area, Fiji does not have any sensitive products on its negative list; products qualify for tariff preference subject to fulfilling the Rules of Origin (ROO) criteria. PNG removed duties from the 400 products in its negative list, with the exception of three products: canned tuna mackerel, cane sugar, and salt. Although Solomon Islands deferred its tariff reduction commitments following the ethnic conflict in 2004, at least 80 per cent of its tariffs are to be reduced to zero by 2015. It is expected that all MSG parties will trade fully duty free amongst themselves by 2017.

This is a significant achievement for the MSG, which had its humble beginnings in 1981, when the founding members came together to pursue common political and economic goals that would benefit their peoples. In 1993, the first MSGTA was signed by PNG, Solomon Islands and Vanuatu as founding members of the MSG. A 'positive list approach' was taken with three products that the countries successfully exported to each other at the time: canned tuna (PNG), beef (Vanuatu), and tea (Solomon Islands). The objective of the MSGTA was to promote intra-MSG trade and strengthen economic cooperation. Fiji's desire to ratify the MSGTA in 1997 boosted the MSG to become a 'formidable entity' in the Pacific (Jayaraman 2012). Over the years, members gradually implemented reforms to reduce tariffs, accompanied by supportive economic policies to facilitate the implementation of the MSGTA. The first review of the MSGTA resulted in the expansion of the initial product list to more than 180 products through a positive list approach.

The MSG's attempts to establish a free trade area in Melanesia have faced stormy waters during the 20-odd years of the agreement. In the mid-1990s, the basic tenets of the MSGTA were put to the test as trade relations between Fiji and Vanuatu became strained following the infamous trade wars on biscuits and kava. Vanuatu placed a one-year ban on biscuits imported from Fiji, which cost the FMF Biscuit Co. Ltd more than FJ\$2 million as containers were held up at the ports and entry declined into Vanuatu (ABC Radio 2012b). Vanuatu unilaterally

2 Products originating from MSG countries - namely Fiji, Papua New Guinea and Vanuatu - were eligible for tariff preferences under the MSGTA, subject to meeting the rules of origin. 
applied the trade ban as it perceived the imported biscuits from Fiji to be undercutting its local biscuit industry. The trade ban measure contravened the basic principles of encouraging free trade within Melanesia. Through diplomatic channels, the Fijian government requested bilateral consultations with Vanuatu within 14 days to resolve the dispute. Vanuatu later revised its position by licensing importers to import only two tonnes of biscuits and imposed an additional 50 per cent import duties. However, Vanuatu's actions did not satisfy the Fijian government, who retaliated by imposing a ban on imports of Vanuatu kava. Vanuatu's kava exports to Fiji sustain the livelihood of many Ni-Vanuatu farmers who rely solely on income earned from this million dollar industry. The ban was finally removed by Vanuatu in 2005. Following the biscuit and kava dispute, PNG threatened to impose more than double import duties on Foods Pacific Ltd's canned beef in retaliation for the Fijian government refusal to allow Ox \& Palm beef into Fiji. Fiji had claimed that, due to quarantine concerns, PNG could only use beef imported from Australia and New Zealand, and substantially transformed in order to qualify for tariff preferences under the MSGTA. This policy did not please PNG, since it had a thriving beef industry. Following concerns raised by the PNG government, biosecurity officials in Fiji visited PNG to inspect the canning facilities to ensure it met Hazard Analysis Critical Control Points (HACCP) standards.

\section{The Formation of the MSG-FTA}

Considering the long history of efforts made to establish free trade agreements in the broader Pacific Islands region, the success of the MSG-FTA is significant. The proposal to explore regional economic integration and a free trade area was mooted from 1971 since the establishment of the Pacific Islands Forum (PIF). ${ }^{3}$ The PIF lacked the political will to consider the concept as the means to bring economic growth and prosperity in the region (Herr 1994). But, more importantly, the economics of trading amongst the scattered islands, and the fact that most countries produced similar goods, presented huge challenges. Even more challenging were the necessary economic reforms to achieve this objective. Regional integration was not developed further as the PIF continued to pursue regional sector initiatives such as the University of the South Pacific (USP) and the Fisheries Forum Agency (FFA). 
In the early 1980s, the forum island countries (FICs) ${ }^{4}$ recognised the need to secure export markets for their agriculture and fisheries resource-based products and secured the first non-reciprocal trade agreement, called the South Pacific Regional Trade and Economic Cooperation Agreement (SPARTECA). SPARTECA provided FICs duty and quota free non-reciprocal market access to Australia and New Zealand. The FICs soon realised the SPARTECA rules of origin were too restrictive for the private sector, this was particularly true for manufactured products such as Fiji garments. The exports of wholly obtained primary produce to Australia and New Zealand were increasing, although strict sanitary and phyto-sanitary requirements were applied. Although SPARTECA was beneficial for Fiji, it made it difficult for the businesses and industries in the FICs to meet the ROO. The non-reciprocal preferences accorded to FICs products through SPARTECA would automatically become redundant once the Australian government had reduced duties to zero, in line with their commitments under other regional trade agreements, such as the APEC goal of eliminating tariffs imposed by developed members by 2010. To date, the average Australian customs tariff hovers around 17 per cent. Due to these glaring realities, the FICs proceeded to develop more favourable ROO that would benefit their exporters and generate economic returns to their ailing economies.

The considerable lack of political consensus to reach new agreement within the multilateral trading system also led to countries pursuing regional integration initiatives. The FICs also faced pressure to enter into reciprocal trade agreements due to the looming deadline for the expiry of the World Trade Organization (WTO) waiver. The waiver, obtained in 2002, allowed the European Union (EU) to extend its non-reciprocal trading scheme to the African, Caribbean and Pacific (ACP) countries under the Lomé II Convention, which facilitated Fiji's sugar and tuna exports to Europe. In 2001, the EU secured an extension of the five-year WTO waiver on its Lomé preferences to allow it to negotiate Economic Partnership Agreements (EPAs) with ACP countries, which included the 14 FICs. Since the EPA would be the first agreement between the FICs and a developed partner, the agreement would be required to comply with the stricter reciprocal WTO rules on regional economic integration. The FICs agreed to negotiate a free trade agreement amongst themselves under PICTA as a stepping stone to integration with the EU through the EPA and with other major partners in the future. This would also facilitate their gradual integration into the global economy and the multilateral trading system, thereby opening up their markets to competition with the rest of the world. The Pacific Islands expansion of trading links among the FICs would bring economic and social

4 The FICs comprise 14 islands in the Pacific: Cook Islands, Federated States of Micronesia, Fiji, Kiribati, Nauru, Niue, Palau, Papua New Guinea, Republic of Marshall Islands, Samoa, Solomon Islands, Tonga, Tuvalu and Vanuatu. The FICs group does not include Australia and New Zealand. 
benefits, and improve the living standards of all peoples. The FICs recognised the desirability of a clearly established and secure framework of rules for trade under conditions of fair competition in the Pacific region.

In its efforts to create regional integration of Pacific Island markets, the PIF leaders endorsed the PICTA. PICTA was seen as the vehicle to strengthen and enhance intra-regional trade between the FICs by eliminating trade-distorting tariffs and non-tariff barriers to trade through progressive and gradual phases in order to achieve a single regional market (PIFS 2012). This regional economic integration strategy was part of the forum leaders Pacific Plan; it was implemented by the Pacific Islands Forum Secretariat. ${ }^{5}$ It took two years for the FICs to negotiate a PICTA trade in goods agreement. Although negotiations on the PICTA trade in goods agreement entered into force in 2003, the FICs faced significant challenges which contributed to the slow, ineffective and unsuccessful implementation of the agreement. Scollay indicated that many of the FICs lacked the capacity to undertake reforms and address inconsistencies in the PICTA and MSG schedule of commitments. Further to this, some FICs do not use automated systems for customs clearance, and some have yet to implement the harmonised system for classification for trade in goods (Scollay 2008). Even though 11 FICs ratified the PICTA, there were further complications, as only seven of the 11 FICs announced their readiness to trade (PIFS 2009).

In 2003, the FICs started negotiations on a WTO-compatible EPA to meet the looming deadline for the expiry of the Cotonou Agreement in December 2006. Since the negotiations were carried out with a developed country, this presented an opportunity for Australia and New Zealand to pursue negotiations for a free trade agreement with the FICs. Australia and New Zealand had strongly argued that they should not be disadvantaged by any trade agreement that the Pacific would negotiate with any other developed country. Noonan stated that the EPA negotiations with the EU were linked to negotiations of the Pacific Area for Closer Economic Relations (PACER) Plus in 2008 (Noonan 2011), which occurred in anticipation of the negotiations on the Interim EPA, which PNG and Fiji eventually signed and ratified in 2007 and 2009 respectively, to protect market access for its products such as canned fish, sugar and garments. PNG's commitments under the Interim EPA also triggered the removal of duties on majority of the products listed on their negative list under the MSGTA, with the exception of salt, sugar, and canned mackerel. The change in PNG's commitments in the MSG provided an opportunity for exporters to freely trade within the sub-region.

5 The Pacific Plan is a high-level framework designed to strengthen regional cooperation and integration in the Pacific. The framework was endorsed by forum leaders in 2005. 
The conclusion of the PICTA negotiations gave the impetus for the MSG countries to review the MSGTA to ensure that the PICTA did not overtake MSG preferences and render the MSGTA irrelevant for its members. A review of the MSGTA was undertaken in 2005 which committed members to reduce tariffs to duty free on a longer positive list of goods within eight years. A new ROO, based on change in tariff heading method, which was much simpler, replaced the value-added ROO in the previous agreement. The review was critical to further promote trade and ensure that the MSG-FTA was proceeding ahead of the other free trade agreements to maintain its relevance.

The significance of the MSG-FTA is also indicated by the fact that although it initially focused on goods, there was also scope for members to create a regional market for trade in services, investment, and labour mobility. In 2012, milestones were achieved with the MSG Memorandum of Understanding (MOU) on Skilled Movement Scheme (SMS) which facilitated the movement of semiskilled personnel within the identified category of skills. Under the SMS, people with specialised skills - such as trained teachers, nurses, engineers, pilots, and doctors - are able to move freely to meet skills shortages within the MSG-FTA. The negotiations of the MSG MOU on SMS also had a profound impact for the MSG, since it only took two years to negotiate, compared to the seven years that it took the FICs in negotiating the PICTA Trade in Services (TIS) agreement. The PICTA TIS is yet to enter into force as only four out of the 14 FICs have ratified the agreement (PIFS 2014).

\section{Political Will and Leadership}

One of the critical factors contributing to the achievement of a MSG-FTA is the vision, political will and determination of the founding and current leaders to establish and advance economic integration in Melanesia. This was not easy, as most Melanesian economies faced significant challenges to creating sustainable economic growth. With increasing calls for globalisation, the MSG had foreseen the profound impact of regional integration on its members' ability to export their products and services in a competitive global environment. Since the region has an abundant supply of natural resources and a population of more than seven million people, there is huge potential for a larger sub-regional market to generate economic activities that would contribute towards employment creation, economic growth and the development of local industries.

Although MSG countries began to gradually liberalise their markets, the economies were highly protective with significant trade and investment barriers that discourage private sector development. The MSG sometimes had its own internal political differences but these were usually resolved the traditional 
'Melanesian way'. In 2010, Vanuatu's Prime Minister Edward Natapei refused to hand over the chairmanship of the MSG to Fiji's Prime Minister Commodore Josaia Bainimarama on the grounds that this would undermine the MSG's democratic ideals. Some claims were made that Australia had instigated the move with the promise of aid to Vanuatu. But the chairmanship issue was resolved in the traditional Melanesian way, a first for the leaders, at a special meeting hosted by the Solomon Islands Prime Minister Danny Philip. The traditional reconciliation ceremony stamped its mark as an alternative avenue for resolving disputes within the MSG and its engagement within the wider Pacific.

In 2011, Bainimarama assumed chairmanship of the leaders' summit in Suva which set a bold vision to achieve future closer economic regional integration towards either a common market or customs union. The vision was to be achieved through a broadening of the MSGTA beyond goods to advance trade in services, investment and labour mobility. It also supported the MSG's plan to proceed at a faster pace than the rest of the FICs, given their aim to strengthen private sector development, attract investment, and create economic opportunities to grow and strengthen their economies. With the MSG members also participating in several other regional trade negotiations, it was realised that preferences accorded within the scope of the MSGTA would erode faster and become ineffective if these regional free trade negotiations superseded the MSG.

As chair of the MSG, Bainimarama also took advantage of this opportunity to share his views on the vision to ensure that the MSG would remain relevant. He was a keen advocate of greater regional cooperation in Melanesia and believed that competition would create business opportunities, and generate economic growth and a prosperous Pacific. Fiji's position as the hub of the Pacific would also support and strengthen the overall vision to achieve regional integration in Melanesia. Bainimarama not only raised the profile of the MSG by advocating issues pertinent to its people, but also enabled the institution to achieve a number of key milestones. The chairmanship was then handed over to Victor Tutugoro of the Front de Libération Nationale Kanak et Socialiste (Kanak and Socialist National Liberation Front (FLNKS)) in New Caledonia, who was expected to carry on the vision of the leaders. ${ }^{6}$

$6 \quad$ Front de Libération Nationale Kanak et Socialiste (Kanak and Socialist National Liberation Front (FLNKS)) is an organisation representing the interests of indigenous people in New Caledonia. Although FLNKS is a political member of the MSG, it is not yet signatory to the MSGTA. 


\section{Making MSG More Relevant}

One of the many reasons attributed to the successful achievement of a MSG-FTA was its members' collective resolve to ensure that the MSGTA remains relevant in the midst of trade negotiations currently taking place in the Pacific. As part of efforts to improve the implementation of the MSGTA, Vellutini and Puech were commissioned by the MSG secretariat in 2010 to assess the implementation of the MSGTA and develop a roadmap for the creation of a common market for services and labour within a two to three year period. Vellutini and Puech found that, although the value of intra-MSG trade was small (around 3 per cent) compared to their trade with the rest of the world, intra-MSG trade was increasing and had enormous potential to increase in future, due the size of the large market of almost eight million people (Vellutini and Puech 2010). The study also found that PNG had become the largest exporter and importer in the region, surpassing Fiji. This result is not surprising considering the unprecedented growth of the PNG economy over the last eight years and its population size of almost seven million people.

One of the challenges in making the MSGTA relevant lies in addressing inconsistencies in implementation at the national level. Vellutini and Puech's study found that PNG and Vanuatu reneged on their commitments by maintaining high tariff barriers and failed to progressively reduce duties on products in their negative lists. Members were required to reduce duties immediately on products within eight years of the coming into force of the revised MSGTA. The general inconsistencies in the application of the tariff levels, the ROOs, and quarantine procedures sent out negative signals and caused a lot of uncertainty for the private sector. The findings of the report were addressed by senior trade and economic officials, who also considered a proposal to review the MSGTA legal text and architecture. Although PNG had been highly protective of its industries, a strategic shift in policy direction took place in 2011, when PNG granted duty free and quota free preferences to the EU under the Interim EPA. PNG was required under the 'Most Favoured Nation Treatment' provisions in the MSGTA to automatically extend the same preferences to other MSG members. ${ }^{7}$ Parties to the MSGTA that enter into free trade agreements with other non-MSG members are required to extend the same tariff treatment to each other, resulting in the benefits flowing to other MSG members. With these developments, PNG duties were removed from more than 400 items listed in its negative list, except for sugar, salt, and canned mackerel. The MSG-FTA thus became operational from

7 The Interim EPA provides for duty-free, quota-free market access into the EU for all exports originating from Fiji and Papua New Guinea. Papua New Guinea signed the Interim EPA in July 2009, and Fiji in December 2009. European parliament approved the agreement in January 2011 and Papua New Guinea ratified it in May 2011. Fiji started to implement the Interim EPA at the end of July 2014. 
1 January 2013 when at least three members (Fiji, PNG, and Vanuatu) effectively began to trade duty free. The other products exempted from zero rates under the MSGTA were alcohol, oil and fuels, tobacco, and cane sugar.

Another major driving factor that contributed to making MSG more relevant is attributed to the establishment of the MSG secretariat. A workable regional integration initiative is highly dependent on the existence of its own effective secretariat. In the early days, the work programs for the relevant committees, such as the trade and economic officials, were driven by members that assumed the chairmanship of the MSG. But the lack of capacities at the national level to facilitate and monitor the implementation of the MSGTA quite often hindered members' initiative and drive to develop work programs. In 2009, the MSG secretariat was established to facilitate the implementation of the MSGTA, identify new areas of cooperation with development partners, and provide policy and technical advice to its members on general matters relating to the MSG (Pacific Institute of Public Policy 2008). There were generous donations of financial assistance and aid in kind received from development partners to support the work program of the secretariat. The Chinese-funded secretariat building is located in Port Vila, Vanuatu.

\section{Increasing Fiji-PNG Trade and Investment Relations}

Another major contributing factor to the achievement of the MSG-FTA is the fact that both Fiji and PNG share and identify with a common vision of closer economic integration as a means of creating economic opportunities for their people. Recently, there have been continuous efforts made to strengthen commercial relations between these two largest economies in the Pacific. PNG has implemented policy changes to trade duty free on goods originating from other MSG countries in its efforts to share much of its income gained from its growth with the Pacific. This has led to PNG prioritising its obligations to pursue the MSGTA over other regional integration initiatives, such as the PACER Plus negotiations with Australia and New Zealand (Islands Business 2013). Fiji, on the other hand, recognises PACER Plus as a means to deepen regional integration with Australia and New Zealand. Fiji joined the PACER Plus negotiations in November 2014, following its successful elections held in $2004 .^{8}$

8 Fiji withdrew from the PACER Plus negotiations due to the Pacific Islands Forum leaders' decision to suspend Fiji on 2 May 2009. 
Historically, Fiji and PNG have enjoyed close and friendly relations ever since the arrival of Fiji's first missionaries in PNG in 1875. Political relations were only established some 100 years later and have since strengthened, with Fiji joining the MSG in 1997. As the largest economies, in the Pacific, Fiji and PNG have the potential to strengthen trade and economic cooperation in the Pacific. PNG, the fastest growing economy in the Pacific, was projected to have grown by around 8 per cent in 2012 and with a population of almost seven million people, there are increasing opportunities for job creation and investments (IMF 2013). PNG is experiencing an unprecedented economic boom driven largely by the construction of the US\$19 billion liquefied natural gas project coupled with strong performance in domestic demand in the construction, transport and finance sectors. PNG has a small manufacturing sector that predominantly produces beer, soap, concrete products, fruit juices, plywood, and paint, but this is growing and diversifying.

Historically, the PNG government had been highly protective of its domestic industries, as is demonstrated by the high tariff rates it levied under the MSGTA. Under the able leadership of Prime Minister O'Neill, the PNG government fasttracked reforms necessary to support the development of the private sector, creating employment, and promoting trade and investment opportunities. Prime Minister $\mathrm{O}^{\prime}$ Neill shared a common vision of a unified Pacific with free movement of goods and people, but it was to be supported by strong national policies to drive economic development (Islands Business 2012). In supporting regional integration, $\mathrm{O}^{\prime} \mathrm{Neill}$ believed there were merits in working together to take advantage of the opportunities that would be mutually beneficial to the Pacific in resolving common issues such as climate change, food security, education, health, and potential investments. Prime Minister $\mathrm{O}^{\prime}$ Neill stated that while PNG is experiencing an economic boom, it lacked the capacity to generate new economic activities to facilitate trade (ABC Radio 2012a). The free movement of goods and labour within the Pacific would provide opportunities in sectors of the economy where PNG lacks qualified and skilled workers, such as tourism and manufacturing.

The boom in the economy has also driven PNG investor interest in exploring other markets and entering into joint venture projects that would generate viable economic returns. In 2012, Prime Minister O'Neill led a strong private sector delegation on an investment promotion mission to Fiji. The mission coincided with the official unveiling of the Pearl South Pacific Resort and the Championship Golf Course in Pacific Harbour, following their acquisitions by PNG companies, and included visits to the PNG-owned Bank South Pacific, and the Grand Pacific Hotel (which is a joint venture project with Fiji). The PNG Mineral Resources Development Cooperation and Petroleum Resources had invested US\$32 million in Pearl South Pacific at Pacific Harbour. PNG's National 
Superannuation Fund and Lamana Development Ltd had invested in the Grand Pacific Hotel in Suva. Prime Minister $\mathrm{O}^{\prime}$ Neill believed that in strengthening trade and investment ties between Fiji and PNG, the private sector could directly benefit from the huge opportunities that could flow into other MSG countries and the wider Pacific region.

$\mathrm{O}^{\prime}$ Neill affirmed that, while Fiji was going through some challenging times, he was encouraged by the developments taking place in the country. The PNG government offered at least 50 million kina to assist Fiji prepare for the 2014 national elections and return to genuine parliamentary democracy. PNG's support for Fiji was further demonstrated in 2012 when $\mathrm{O}^{\prime}$ Neill offered to host the special Pacific ACP Leaders Meeting in Port Moresby to resolve Fiji's concerns about its participation at all levels of the Pacific ACP forums. The PNG government also offered to host and fund an interim Pacific ACP secretariat.

Fiji, as the hub of the Pacific, and with its large manufacturing base, connectivity to the Pacific and strong infrastructure, views itself as an equal partner to explore trade and investment relations with other members, with the hope of improving the lives of every Melanesian. Fiji has a favourable trade balance with PNG, and as a competitive supplier, this trend is expected to grow in the future. Foreign direct investments also play a significant role in economic development, and already there has been a fairly good exchange of businesses operating in both countries. Some Fijian companies have invested in PNG in the areas of manufacturing, construction, hotels and restaurants. Fijian companies already operating in PNG include Punjas (PNG) Ltd, Foods Pacific Ltd, Datec (PNG) Ltd, and Hardware Haus Ltd. The growing PNG economy augurs well for Fiji's manufacturing business, and encourages more cargo, thus enhancing business for the shipping lines. There is also considerable scope to encourage investments within Melanesia, which has already materialised through cross border movements of MSG business ventures such as PNG's Bank South Pacific and Vanuatu's Bred Bank.

In his quest to strengthen trade and investment relations with PNG and take advantage of the available opportunities, Fijian Prime Minister Bainimarama led a 70-member government and private sector delegation on his inaugural state visit to Port Moresby in 2013. The objective of the mission was to promote Fijian products and services, explore trade and investment opportunities, and discuss the common vision of PNG and Fiji leading the MSG into economic union. As a result of the trade and investment mission, several Fijian companies secured orders and entered into business agreements with PNG suppliers and distributors, and two companies have registered with the PNG Investment Promotion Authority to set up businesses in PNG. Prime Minister Bainimarama also announced plans to appoint a trade commissioner to PNG, who will be responsible for promoting trade and investment, and boosting networking 
relationships with Fiji and PNG companies and other major stakeholders. A budget of FJ $\$ 890,000$ has been allocated in 2015 to facilitate the setting up of Fiji's Trade Commission Office in PNG. The prime ministers announced that both countries will no longer require visas to facilitate the travel of citizens and business people. Further work will need to be undertaken by the respective government agencies, through a Fiji-PNG Investment Working Group, to discuss opportunities and enable government to explore ways to address bottlenecks that prevent trade and investment activities. The first Fiji and PNG senior officials meeting was convened in Suva in February 2015 to discuss plans and future engagements, with the view to strengthen existing relations between both countries. The increase in cooperation and collaboration between Fiji and PNG clearly indicates that opportunities for trade and investment can be tapped and harnessed to create mutual benefits for the countries and, in turn, stronger growth for the MSG region.

\section{Conclusion}

Since its humble beginnings in 1983, the MSG has made leaps and bounds, particularly with the creation of the free trade area from 1 January 2013. The MSG-FTA allows qualifying products to trade freely between Fiji, PNG, and Vanuatu. Solomon Islands has also progressively taken steps to remove tariff barriers and to trade freely with other members in $2017 .{ }^{9}$ The creation of the free trade area bears testament to the political will, determination and collective efforts of the MSG leaders to make the MSG more relevant in the midst of increasing pressures to negotiate more free trade agreements within the Pacific. The MSG also places utmost importance on achieving its broad goals to provide economic opportunities and achieve sustainable economic growth.

To improve the implementation of the MSGTA, tariff barriers were reduced and inconsistencies addressed, which generated new trade and investment opportunities within Melanesia. The growing trade and investment relationship between Fiji and PNG clearly demonstrates the improvements in strengthening of business to business contacts that are mutually beneficial to both parties. The conclusion of the MSG Skills Movement Scheme will add to the success of the MSGTA. A new MSGTA that consolidates goods investment — and expands it into services investment - and labour mobility is currently under negotiation by members, making it (once concluded) the most progressive in the Pacific.

9 Solomon Islands have removed duties levied on 80 per cent of its products from 2013, with the remaining products to be duty free by 2017 . 


\section{References}

ABC Radio, 2012a, 'Fiji and PNG Trade Growth Could Affect Forum Influence', interview with Waden Narsey, 28 November. Available at: www. radioaustralia.net.au/international/radio/program/pacific-beat/fiji-and-pngtrade-growth-could-affect-forum-influence/1052870.

ABC Radio, 2012b, 'Vanuatu Ban on Fiji Biscuits may Spark Trade War', interview with Hari Punja, Punjas Group Chairman, Pacific Beat, March.

Herr, R.A., 1994, 'Regionalism and Nationalism', in K. R. Howe, R. C. Kiste and B.V. Lal (eds), The Tides of History, Allen and Unwin, Sydney.

International Monetary Fund (IMF), 2013, 'IMF World Economic Outlook: October 2013: Transitions and tensions', IMF, Washington. Available at: www.imf.org/external/pubs/ft/weo/2013/02/.

Islands Business, 2012, 'Peter O'Neill's Pacific Plan: The PNG push into the region', November.

Islands Business, 2013, 'PNG's Trade Minister Keen for a Common Market in MSG Nations', interview with PNG Minister for Trade, Mr Richard Maru, May, Suva, Fiji.

Jayaraman, T.K., 2012, 'How MSG Leads the Trade Way', Fiji Sun, October 13. Available at: tkjayaraman.com/docs/2012/np_articles/How\%20 MSG $\% 20$ leads $\% 20$ the $\% 20$ trade $\% 20$ way_FIJI $\% 20$ SUN_Saturday $\% 20$ October\%2013\%202012.pdf.

Noonan, C., 2011, 'PACER Plus Progress and Promise: Regional integration challenges and opportunities in the Pacific', Trade Negotiations Insight. Available at: www.ictsd.org/bridges-news/trade-negotiations-insights/news.

Pacific Institute of Public Policy, 2008, 'MSG: Trading in political capital and Melanesian solidarity'. Available at: www.pacificpolicy.org/wp-content/ uploads/2012/05/D02-PiPP.pdf.

Pacific Islands Forum Secretariat (PIFS), 2009, 'PICTA Status Report: 3 March, 2009'.

PIFS, 2012, ‘Pacific Island Countries Trade Agreement (PICTA): Frequently asked questions'. Available at: www.forumsec.org/resources/uploads/attachments/ documents/PICTA_FAQ_Jun2012.pdf.

PIFS, 2014, 'PICTA TIS Status Report: 25 March, 2014'. 
Scollay, R., 2008, 'Assessment of the Extent of Trade Liberalisation in Pacific Island Countries (PICs) and Review of the Pacific island Countries Trade Agreement (PICTA)', Pacific Islands Forum Secretariat, Suva.

Vellutini, C. and F. Puech, 2010, 'Study on the Implementation of the MSG Trade Agreement and the Roadmap for Future Integration', European ConsensusPlatform for Alternatives. 
This text is taken from The New Pacific Diplomacy, edited by Greg Fry and Sandra Tarte, published 2015 by ANU Press, The Australian National University, Canberra, Australia. 